\title{
Occupational Structure in European Countries: What do Forecasts Predict? ${ }^{1,2}$
}

\author{
N. Vishnevskaya, A. Zudina
}

Nina Vishnevskaya, PhD - Deputy Director, Centre for Labour Market Studies, National Research University Higher School of Economics; 20 Myasnitskaya str., 101000 Moscow, Russian Federation; E-mail: vishnev@hse.ru

Anna Zudina, PhD - Research Fellow, Centre for Labour Market Studies, National Research University Higher School of Economics; 20 Myasnitskaya str., 101000 Moscow, Russian Federation; E-mail: azudina@hse.ru

This paper analyzes the future occupational structure of the labour force in European members of the Organisation for Co-operation and Development (OECD). Occupational structure forecasts allow researchers to evaluate the quality of job openings and, consequently, overall future labour market performance. Identification of demand for certain occupations in Europe can facilitate assessment of whether processes occurring in the Russian labour market are consistent with global trends.

The paper discusses the methodology of labour force forecasting and basic research approaches to the prediction of occupational structure changes. It emphasizes the dynamics of demand for representatives of certain occupations in Europe by identifying the fastest growing and declining occupations and suggests possible reasons for changing demand. The paper demonstrates that the main occupational trend over the next decade will consist in the increasing importance of professionals, as well as technicians and associate professionals. The increase in demand for health professionals and representatives of occupations providing scientific and technological innovation will be most significant. At the same time, it is expected that demand for elementary occupations will also rise. This process will evolve simultaneously with the decrease in the total number of skilled and semi-skilled blue-collar occupations due to globalization and the reduction of industrial production in developed economies. The ongoing "mechanization" of many job functions will not eliminate the need for occupations such as cleaners, labourers, domestic servants or personal workers. The need for these jobs allow employees with low levels of education to enter the labour market rather than depending on the social benefit system. Another tendency for all countries with developed economies will be reduced demand for many whitecollar occupations as modern computer technologies and the automation of many routine functions previously performed by office workers becomes more prevalent.

Key words: Occupational structure; Forecasting; Labour market, Europe; OECD; Labour demand; Job quality

For citation: Vishnevskaya N., Zudina A. (2017) Occupational Structure in European Countries: What do Forecasts Predict? International Organisations Research Journal, vol. 12, no 4, pp. 109-129 (in Russian and English). DOI: 10.17323/1996-7845-2017-04-109

${ }^{1}$ The editorial board received the article in October 2016.

${ }^{2}$ Support from the Applied Research Program of the National Research University Higher School of Economics is gratefully acknowledged 


\section{Introduction \\ Relevance and motivation of the study}

In any country, the labour market is in a constant state of flux, with changes in the occupational structure of the workforce reflecting key trends in economic development. The growing demand for certain occupations and the difficulties in finding employment for people with outdated professional knowledge and skills is influenced by several parallel processes, the most important of which are sectoral shifts in the economy, competition in commodities markets, globalization and technological progress.

Forecasting society's occupational structure is important for many economic agents. The expected changes in the structure of labour demand are important for the education system, whose main task is to provide training for professions that are in demand. Forecasts of the occupational structure are the basis for making decisions on hiring and retraining employees, thereby determining opportunities for further growth in labour productivity. Without a clear idea of the major changes in the structure of employment, it is impossible to formulate effective policies in the labour market. Additionally, assumptions about a possible deficit within certain occupations help to foster a competent migration policy. Consumers of information about the forthcoming changes in the labour market also include young people who are choosing a career path. Such knowledge is also important for older workers, who may seek a different career path or want to obtain training in order to remain competitive.

This article aims to analyze the future occupational structure of European OECD countries, which include the developed states as well as a number of transitional economies. Existing occupational forecasting studies for European countries tend to narrowly focus on forthcoming changes in demand for large occupational groups. In our opinion, it is necessary to study in detail which specific occupations will grow, as well as which will decline. The discussion of the dynamics of demand for different occupations is traditional for the US labour market, but such publications have no readily-available analogue in Europe.

Analyzing the future structure of the relevance of various occupational categories allows one to determine the quality of newly-created jobs: if they will be predominantly "good" jobs which command a high salary and require a high level of skills, or if the demand for labour is distributed more evenly between different occupational categories, or if demand for employees will reflect a U-shaped scenario. In the latter case, the most and least qualified employees will be in demand, while employment opportunities for those with an average level of qualification will be sharply narrowed. The effectiveness of the labour market won't just depend on where the new jobs will be concentrated. Under a U-shaped scenario, work available to those with mid-level qualifications will dry up. In developed countries, these employees constitute the largest segment of society; if their numbers dwindle, it can result in more socio-economic inequality. 
It is important not only to draw the expected "picture" of the occupational structure, but also try to explain what causes contribute to the fact that the demand for certain occupations is growing rapidly, while others are also rapidly declining. The predictions of the occupational structure in European countries, which are Russia's neighbors and partners, are of interest not only from the point of view of understanding the future state of their labour markets. Identifying the specifics of demand for individual professional groups in other countries seems to be useful for understanding how events in Russia correspond to world trends.

\section{Forecasts of the occupational structure: causes, main tasks and classifications}

Forecasting an occupational structure is a relatively new field of economic research. The USA and Canada were pioneers in this field; they first started predicting how the structure of the workforce would change in the late 1950s. These two countries have made significant progress in developing the methodology for forecasting and preparing the appropriate statistical base. The US still holds leading positions in this field, developing the most detailed forecasts. In European countries, occupational structure forecasts were first organized later, in the mid-1960s. Since the 1990s, countries with transitioning economies have also been actively involved in the process of "anticipating" the future.

In European countries, the intensification of occupational structure forecasts was due to two main reasons. First, the increased understanding of the importance of workforce quality in promoting economic growth, which has been established among researchers of various theoretical schools and government officials. This problem gained more recognition following a study published by E. Denison in 1962, which was devoted to exploring sources of further economic growth [Denison, 1962]. The second reason was related to the fear that there would be a shortage of various categories of workers, especially skilled workers, amid the economic recovery of the 1960s.

The history of forecasting shows not only the improvement of technical forecasting tools; significant changes have been made to their goals and main tasks. During the first period, which lasted until the mid-1970s, it was believed that by identifying future trends in the occupational structure, the education system would receive the most accurate guidelines for training workers needed by the economy. In those years, it was widely held that such forecasts can play a decisive role in balancing demand and supply in the labour market, which in turn would solve the problem of labour shortages in many occupations, especially ones that required specialized qualifications.

However, the initial experience of countries that actively joined in the work of drafting occupational structures showed that such expectations are overestimated. Detailed, reliable forecasts for individual occupations have proved extremely difficult. In addition, the education system and business could not make full use of the available 
forecasts, not only due to remaining doubts about their accuracy, but also because the necessary knowledge and skills for a particular occupation can be obtained in different ways [Hughes, 1993].

The tasks of present-day occupational structure forecasts can be considered less ambitious, but much more realistic. Now, forecasts are expected to determine the trajectory of changes in the occupational structure of the workforce that may occur in any given scenario of economic development. Users of these forecasts, including state officials, employers, educational institutions and those choosing a career, have material for reflection rather than a direct guide. The change in priorities had one more consequence. Although in most countries the number of professional categories for which forecast estimates are made has increased significantly, detailed forecasts for individual specialties don't exist. In addition, forecasts are not made for individual years, but only for a certain, usually ten-year period.

When forecasting the occupational structure of the economy, the main sources of information are labour market surveys and national accounts data. Each of the sources has its pros and cons. The advantage of surveys is their regularity (in developed countries - at least once a quarter, and in many countries - on a monthly basis). Moreover, in the EU countries, a precise methodology is used. The national accounts data contain indicators such as output and labour costs, and therefore they are often used in the construction of forecast models. As supporting data, various surveys are used, particularly employers' surveys, but these data are mainly needed for short-term forecasting.

In the developed countries, the forecasting, as a rule, enjoys massive state support. However, the direct producers of this work are not always state entities. Perhaps paradoxically, state institutions are responsible for this work in two countries that are thought of as being free-market-oriented - the USA and Canada. In Europe, this work is done by non-profit organizations, such as the English Institute for Employment Studies of the University of Warwick or the German Institute for Employment and Occupational Research at the Federal Institute of Labour in Nuremberg. Some researchers attribute this "detachment" of the state in European countries from the organization of forecasting to the fact that in these countries the authorities, which are to a large extent tasked with "responding" to the economic situation, are afraid to take responsibility for the quality of the forecast estimates [Zukersteinova, 2007].

In addition to forecasts that are developed by specialists in individual countries, there are forecasts for groups of countries, and particularly for the countries of the European Union. This is the work of the European Centre for the Development of Vocational Training (CEDEFOP), which we have used to analyze the future trends of the occupational structure of European countries at the level of disparate professional categories.

Inter-country comparisons of occupational structure forecasts are impossible without the use of an identical or at least similar classification of occupations. The definition of professional affiliation must be scientifically justified, stable over time 
and universally recognized. These requirements are met by the International Standard Classification of Occupations (ISCO). The first version of the ISCO was adopted in 1988, and the second, modernized version, was introduced in 2008. It is this classification that is used in continental Europe (in contrast to the United States and Great Britain, where other classifiers are used).

The ISCO-08 is a hierarchical structure of classes, consisting of four levels. At the fourth, most detailed level, all occupations are classified into 436 groups, which in the third level are grouped into 130 categories, and at the second level are split into 43 groups. The first level presents occupations in their most generalized form, which includes 10 groups of classes [ILO, 2012].

The International Classification of Occupations 2008 is based on two basic concepts: the type of work performed and the necessary qualifications. The latter in turn has two dimensions: the level of qualification (which is a function of the complexity and variety of tasks and duties of the employee) and specialization, which is determined by the amount of necessary knowledge, as well as the tools and equipment used. One feature of the latest version of the classifier is the priority value of the required level of knowledge and qualifications for determining the professional affiliation of the employee [ILO, 2012]. The new classification was intended to become a definite standard for the statistical offices of European countries, in order to promote the further unification of statistics for determining the professional affiliation of workers. The transition of European countries from ISCO-88 to the modernized version of the ISCO, the ISCO-08 (which actually happened only in 2011) led to a certain "shake-up" of the occupational structure, especially of individual professional group [Stehrer, 2013]. This, in turn, made it difficult to build long historical series, and, therefore, complicated the forecast work. The overwhelming majority of countries did not recalculate data for the past years based on the new classification, so the data on the occupational structure of the labour force before and after 2011 are not fully comparable. It is for this reason that currently available forecasts for the EU countries until 2020 are based on the ISCO-88 classification, and some attempts to recalculate data on the occupational structure from the new classification are still of an experimental nature [Coping with changes, 2014].

\section{The main approaches to forecasting the occupational structure of the labour force}

The empirical data, the analysis of which is presented in this paper, are based on the European forecast of the occupational structure of the labour force, prepared by $\mathrm{Ce}$ defop [Future skills supply and demand in Europe, 2012]. We emphasize that the main feature of this data is that, firstly, they allow us to look at the European labour market as a whole, and secondly, the forecast of the occupational structure is an integral part of the forecast of supply and demand in the labour market. 
The future demand for labour can be schematically represented in the form of a matrix in which all professional groups are represented horizontally, depending on the industry in which they are concentrated, and vertically, based on the branches of the economy. The size of a particular professional group can vary depending on two factors: (a) the dynamics of production in a particular industry, which implies the same rate of change in the numbers in all professional categories in the industry, and (b) the influence of factors such as technical progress, according to which the change in individual professional category numbers will occur at different rates. Therefore, the forecast of changes in the occupational structure of the workforce is based on an assessment of future changes in the sectoral structure of the economy.

The professional breakdown of the future structure of the workforce depends not only on the level and dynamics of the possible demand, but also on how fully and quickly the education system can meet changing demand, i.e. on the structure of the labour supply. In the supply matrix of the workforce, professional categories are represented horizontally and levels of education vertically. In this case, the main difficulty lies in the fact that there are different opportunities to obtain the same profession, and workers with a certain level of education can find jobs with higher or lower requirements for the educational level. Another limitation is demographic indicators, in particular, the age structure of the economically active population. The principle of the matrix is laid out in such models as the RAS Model, which is used in the Cambridge Growth Project, the Markov Model and many others.

As can be seen in Fig. 1 (right side), the prognosis of the occupational structure consists of interconnected modules, each of which solves a specific problem.

For calculations of each of the modules, a corresponding database is used. For occupational structure forecasts, the main sources of information are labour market surveys.

The forecasting begins with Module 1, within which the number of employees broken down by economic sectors is forecasted. The basis of this module is the intersectoral macroeconomic model (E3ME) used by Eurostat. In the occupational structure forecasting module (module 2 - EDMOD), using the extrapolation method and other more complex econometric methods, estimates of the net change in the number employed in the occupational context for individual sectors of the economy at the end of the forecast period are calculated. Module 3 (QUALMOD) broadcasts expected changes in the number of people employed in three main skill levels, which in turn are consistent with the three levels of formal education in the International Standard Classification of Education (ISCED). The ISCED 1 and ISCED 2 groups represent the lowest level of qualifications; group ISCED 3 and ISCED 4 - medium, and finally, the groups ISCED 5 and ISCED 6 represent the highest educational levels.

Since it is important for the forecast to determine not only the number of newlycreated jobs for different occupations, but also to estimate how many jobs will be made available as a result of retirement, a transition to economic inactivity, emigration and professional mobility, a special module is added. In this case, this is module 4: "Replacement demand module." 
When constructing a forecast of replacement demand, the expected levels of employment by occupation and skill level obtained in modules 2 and 3 along with data on the possible mobility of workers are used. The occupational structure of individual age groups can vary significantly; in order to estimate the scale of "substitution," data on the age and gender structure of the workforce and age of retirement are needed. The mobility of certain age groups is attributable to various factors. If, for example, older workers are more likely to leave the workplace due to retirement, young people do this mainly for reasons such as job mobility, maternity leave (and related family concerns), and immigration. Labour market surveys make it possible to analyze the demographic composition of each professional group and, consequently, determine the retirement age of workers in the profession.

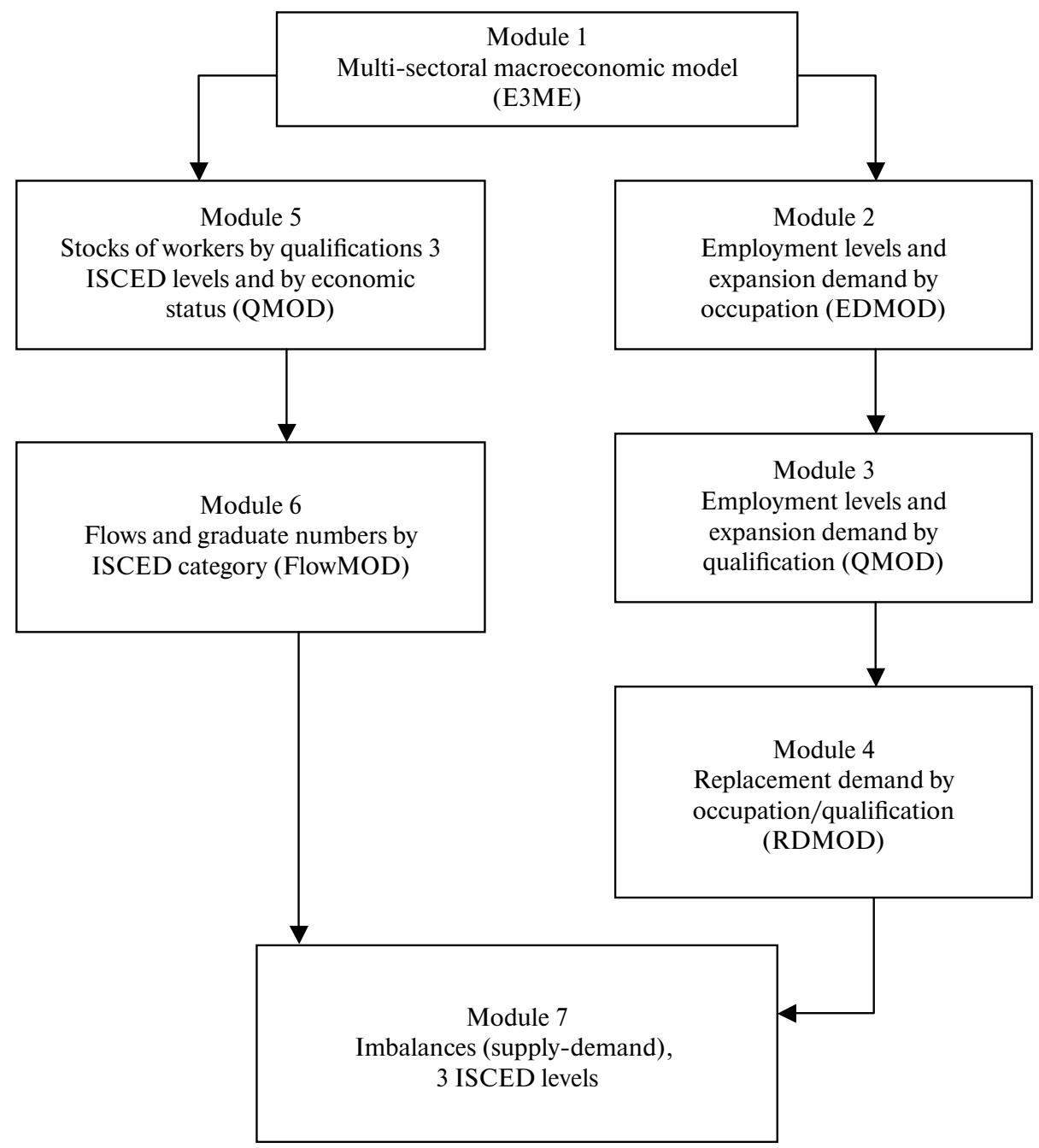

Fig. 1. Conceptual framework of modelling skills supply and demand

Source: Coping with Changes, 2014. P. 63 
The left side of Fig. 1 schematically shows the methodology for forecasting the supply of labour in terms of occupations and skill level, broken down by age and sex for the whole population and for its economically active segment. ${ }^{3}$

Summing up everything is module 7 , which reflects possible imbalances between the supply and demand of labour for the forecast period. However, this apparent imbalance does not consider individual occupations, but only three basic levels of qualifications. Forecasting the imbalance from the standpoint of individual occupations is not yet possible, since such an operation should take into account the many factors that cannot yet be reflected in the applied model.

In the next section, we proceed to assess the future structure of the European labour force, performed on the basis of the Cedefop forecast data, published in absolute numbers. The peculiarity of our analysis is that we focus on separate professional groups and, particularly interestingly, we determine future demand for new and replaced professions.

\section{European labour market - occupational structure forecast}

\section{Occupational groups - forecast of net change}

The employment structure in European countries by occupation is presented in Table 1 (in addition to the 27 EU countries, the forecast includes data on Norway and Switzerland). An analysis of the occupational structure forecast provides the answer to several questions. Will employment increase, or should the situation on the European labour market be described as stagnation? Will trends in the dynamics and the occupational composition of employment that have characterized it in the past continue, or should education policy-makers be prepared for significant changes in the structure of labour demand? Finally, one of the main questions is: will there be a gradual increase in the share of skilled labour and, simultaneously, a washout of those with a low level of qualification from the labour market, or will labour market demand be characterized by a U-shaped scenario? The latter suggests that the growth of jobs for skilled and unskilled labour will be accompanied by subsiding demand for mid-level occupations.

As can be concluded from the figures presented, at the beginning of the current decade, white-collar occupations dominated in the structure of European employment (Occupational groups No 1, 2, 3 of ISCO-88). The largest occupational group was represented by technicians and associate professionals (group 3), whose share in total employment reached $17 \%$. The second largest occupational group consisted of professionals (group 2), the specific weight of which exceeded 15\%. Legislators, senior officials and managers (group 1) account for about $9 \%$ of the total number of employees. Thus, professionals from the first three one-digit ISCO-88 groups were engaged in

${ }^{3} \mathrm{~A}$ more detailed analysis of the methodology for forecasting the supply of specialists of various qualifications, based on an assessment of the prospects for the development of education and training systems, is beyond the scope of this paper. 
skilled work and had, as a rule, a type A or B tertiary education, accounting for more than $40 \%$ of all employed. Clerks (group 4) and service workers and shop and market sales workers (group 5), who can be classified as "white-collar workers" with mid-level qualifications, accounted for almost a quarter of all employed.

The remaining $35 \%$ of the European workforce was engaged in blue-collar occupations (groups 6-9): craft and related trades workers (13\%), plant and machine operators and assemblers (8\%), and elementary occupations (10\%). Skilled agricultural and fishery workers (group 6) belonged to the smallest cohort - their share did not exceed $4 \%$.

By 2020, according to the forecast, the aggregate employment in European countries, i.e. the ratio of the projected increase in the number of workers in a certain occupation in 2020 related to the number of workers in this occupation as of 2010, will grow, although this increase will be small (only 3.6\%). However, the expansion of labour demand will affect various occupational groups differently.

The fastest-growing occupational group will be technicians and associate professionals, whose number will grow by $13 \%$ by 2020 , which will allow them to remain the most numerous cohort in the European labour market (see the third column of Table 1). By the beginning of the next decade, this group will occupy $18.3 \%$ of Europe's total workforce, compared with $16.8 \%$ in 2010 . Such growth will be achieved, first of all, by an increase in the number of jobs for teaching associate professionals, whose number by 2020 will increase by one third. Also the need for life science and health associate professionals will increase by more than $11 \%$. The high growth rates of jobs that require tertiary-type B education in these two industries that traditionally demand the most qualified workers not only testify to the increased demand for educational and medical services, but also point to the redistribution of functions between the two groups of specialists. Professionals with a tertiary-type B education are increasingly taking on certain functions that were previously performed by only the most qualified personnel, thus ensuring a more efficient distribution of labour within a skilled workforce segment.

A significant increase will also be observed among occupations which collectively fall in the so-called "Others" group (by 15\%); group 34 of ISCO-88. These include associate professionals with a tertiary-type B education as legal associate professionals, certain categories of government officials, accountants, real estate agents and sales representatives. Finally, employment among physical and engineering science associate professionals will increase by $6 \%$ (group 31 ).

By 2020, the number of professionals will also grow, but at a slightly slower pace than those with mid-level qualifications. Over the ten-year period, this group will grow by $8 \%$, and their share in total employment will rise from 14.9 to $15.5 \%$. The expansion of this occupational category in the structure of employment will be achieved mainly due to the increase in demand for physics, mathematics and engineering science professionals (by about 14\% compared to 2010), as well as professionals who fall into the "Others» category. It includes such occupations as qualified accountants, market analysts, judges and lawyers, as well as writers, translators and composers (growth of this group will be about 19\%). 
Table 1. Dynamics of employment structure by occupation, European countries, 2010-2020

\begin{tabular}{|c|c|c|c|}
\hline \multirow{2}{*}{ Occupational groups according to ISCO-88 } & \multicolumn{2}{|c|}{ Share, \% } & \multirow{2}{*}{$\begin{array}{l}\text { Dynamics of the size of } \\
\text { the group in } 2010-2020 \\
\text { related to the } 2010 \\
\text { size, } \%\end{array}$} \\
\hline & 2010 & 2020 & \\
\hline 1 Legislators, senior officials and managers & 8.4 & 8.8 & 8.0 \\
\hline 11 Legislators and senior officials & 0.2 & 0.2 & 6.6 \\
\hline 12 Corporate managers & 4.8 & 5.0 & 9.2 \\
\hline 13 Managers of small enterprises & 3.5 & 3.6 & 6.4 \\
\hline 2 Professionals & 14.9 & 15.5 & 8.2 \\
\hline 21 Physical, mathematical and engineering science professionals & 3.9 & 4.2 & 13.9 \\
\hline 22 Life science and health professionals & 1.8 & 1.8 & -1.1 \\
\hline 23 Teaching professionals & 4.0 & 3.5 & -7.2 \\
\hline 24 Other professionals & 5.3 & 6.1 & 18.8 \\
\hline 3 Technicians and associate professionals & 16.8 & 18.3 & 13.0 \\
\hline 31 Physical and engineering science associate professionals & 3.8 & 3.9 & 6.4 \\
\hline 32 Life science and health associate professionals & 2.8 & 3.0 & 11.3 \\
\hline 33 Teaching associate professionals & 1.3 & 1.6 & 30.4 \\
\hline 34 Other associate professionals & 8.9 & 9.9 & 14.7 \\
\hline 4 Clerks & 10.6 & 9.5 & -7.3 \\
\hline 41 Office clerks & 8.5 & 7.9 & -14.5 \\
\hline 42 Customer services clerks & 2.0 & 2.4 & 22.5 \\
\hline 5 Service workers and shop and market sales workers & 14.0 & 14.0 & 3.6 \\
\hline 51 Personal and protective services workers & 9.1 & 9.0 & 2.6 \\
\hline 52 Models. salespersons and demonstrators & 4.9 & 5.0 & 5.4 \\
\hline 6 Skilled agricultural and fishery workers & 4.2 & 3.7 & -9.4 \\
\hline 7 Craft and related trades workers & 12.7 & 11.5 & -6.0 \\
\hline 71 Extraction and building trades workers & 5.6 & 5.8 & 5.0 \\
\hline 72 Metal, machinery and related trades workers & 4.7 & 3.9 & -14.5 \\
\hline 73 Precision, handicraft, printing and related trades workers & 0.5 & 0.4 & -15.9 \\
\hline 74 Other craft and related trades workers & 1.8 & 1.5 & -15.0 \\
\hline 8 Plant and machine operators and assemblers & 7.7 & 7.5 & -0.1 \\
\hline 81 Stationary plant and related operators & 0.9 & 0.9 & 6.7 \\
\hline 82 Machine operators and assemblers & 3.6 & 3.5 & 0.8 \\
\hline 83 Drivers and mobile plant operators & 4.1 & 3.9 & -2.4 \\
\hline
\end{tabular}




\begin{tabular}{|l|c|c|c|}
\hline \multicolumn{1}{|c|}{ Occupational groups according to ISCO-88 } & \multicolumn{2}{|c|}{ Share, \% } & $\begin{array}{c}\text { Dynamics of the size of } \\
\text { the group in 2010-2020 } \\
\text { related to the 2010 } \\
\text { size, \% }\end{array}$ \\
\cline { 2 - 4 } & $\mathbf{2 0 1 0}$ & $\mathbf{2 0 2 0}$ & $\mathbf{1 0 . 7}$ \\
\hline 9 Elementary occupations & $\mathbf{1 0 . 1}$ & $\mathbf{1 0 . 8}$ & 6.7 \\
\hline 91 Sales and services elementary occupations & 6.6 & 6.8 & 15.6 \\
\hline 92 Agricultural, fishery and related labourers & 0.8 & 0.9 & 19.1 \\
\hline 93 Labourers in mining, construction, manufacturing and transport & 2.8 & 3.2 & 3.6 \\
\hline Total employment* & 100.0 & 100.0 & \\
\hline
\end{tabular}

* Total employment also includes the category of armed forces, however Cedefop doesn't publish data on the forecasts of the dynamics of its size.

Source: Own calculations on the basis of Cedefop Forecasts Data. ${ }^{4}$

The forecast for the European countries confirms the tendency toward a gradual compression of demand for workers in the 4th ISCO-88 group, which includes office clerks and customer service representatives. Jobs in this group are the least qualified of all "white-collar" occupations. By 2020, the number of office clerks, who until quite recently were in one of the most in-demand occupational groups, will decrease by $15 \%$. The decline in demand for this category of work is directly related to the widespread use of computer technology and the automation of many routine functions previously performed by office workers. However, the reduction in the need for office workers will be compensated to a certain extent by the expansion of the neighboring occupational group, which also belongs to group 4 of ISCO-88. The number of customer services clerks (such as cashiers and client information clerks) compared to 2010 will increase by almost $23 \%$. Overall employment in Group 5 of ISCO-88 will increase by $7 \%$ as a result of the growth of this category of clerks, but this will not save the share of this group in the labour market: it will decrease from 10.6 to $9.5 \%$ during 2010-2020.

The role of another occupational group, service workers and shop and market sales workers, will increase insignificantly. By 2020 their total number will increase at a rate similar to the general increase in employment, that is, by $3.6 \%$. At the same time, they will remain the third largest occupational group, with a share of $15 \%$ of total employment (their share of the labour market will remain unchanged in 2010-2020).

Groups that suffer significant "losses" in the labour market include the majority of "blue-collar" occupations. The number of skilled agricultural and fishery workers will drop by almost ten percent. However, taking into account the size of this group this occupation in 2010 was among the least common - this will have little effect on overall employment. In addition to this group, the number of craft and related trades workers also will decrease by $6 \%$ according to forecasts. This decline will be mainly

${ }^{4}$ Forecasting skill demand and supply. Available at: http://www.cedefop.europa.eu/en/eventsand-projects/projects/forecasting-skill-demand-and-supply (accessed: 17 October 2017). 
caused by a reduction in the number of metal, machinery and related trades workers, as well as precision, handicraft, printing and related trades workers. The number of plant and machine operators and assemblers will remain practically unchanged, therefore the share of this group will decrease by only $0.2 \%$, to $7.5 \%$. The only subgroup of craft and related trades workers that will show a positive employment trend will be extraction and building trades workers. The growth in the number of such workers will still be small and amount only to $5 \%$ by 2020 . In the "blue-collar" occupations in general, the number of those employed by 2020 will decrease by $15 \%$ compared to 2010 .

In the segment of blue collar workers' occupations, the only occupational group which will grow in 2010-2020 (by 7\%) will be elementary occupations (Group 9); its share in total employment will grow from $10.1 \%$ to $10.8 \%$. The number of jobs among different subgroups will increase more significantly. Thus, employment among agricultural, fishery and related labourers will be $16 \%$ higher than in 2010 , and almost onefifth higher among labourers in mining, construction, manufacturing and transport. The expansion of demand for the most unskilled labourers is considered by a number of researchers as a confirmation of the U-shaped scenario of occupational structure dynamics, when not only qualified specialists but also workers with a low level of education and vocational training are in demand, while the "middle" occupational groups are compressed in their size [Crouch, 2010].

\section{Disaggregated occupations: leaders of growth and decline}

The transition to reviewing the structure of the workforce using a larger, more detailed set of occupational categories (the three-digit level of ISCO-88 classification) allows us to identify the top-20 occupations that will expand most dynamically in the next decade and the top-20 occupations that will most actively reduce their presence in the European labour market (see Table 2 below) .

What do the figures presented in Table 2 tell us?

First, it should be emphasized that the occupations that are included among the top 20 most dynamically expanding can be found in almost all major occupational groups (except Group 1). Secondly, the dynamics of demand for these occupations significantly outperforms the average level and ranges from 15 to $38 \%$. Third, attention should be drawn to the fact that many of the rapidly growing occupations suggest direct personal contact between the employee and the consumer of his service. The top 20 includes sales consultants, street vendors, employees working with clients from different areas, instructors and teachers' assistants. As D. Autor and D. Dorn noted, occupations that presuppose compulsory interpersonal communication, that are often concentrated in the service sector are unlikely to be replaced by technology someday [Autor, Dorn, 2013]. The high demand for occupations that have fallen into the top-list is largely explained by the fact that these occupations refer to those types of activities that cannot be broken down into many routine operations and thus automated. Fourthly, the most sought-after professionals in the labour market will be those with a tertiary education 
of type A or B, engaged in actively developing scientific fields (including not only exact and natural sciences but also social sciences) and physical labourers (transport labourers and metal-processing-plant operators, painters and cleaners).

Table 2 also demonstrates 20 occupations (the tree-digit level of ISCO-88 classification), which are increasingly "rejected" by the labour market. More than the half of the occupations that were included in this list relate to Group 7 in the ISCO-88 classification (craft and related trades workers). Their employment becomes more and more vulnerable to such factors as the globalization of the modern economy, technological progress and changes in consumers' behavior. Thus, the reduction in the employment of workers involved in food processing and textile, garment, pelt, leather and shoemaking trades workers is explained by the transfer of production in the corresponding industries to less developed countries, primarily, the countries of South-East Asia.

The same can explain the decline in forecasted employment indicators for workers in agriculture and forestry, as well as fishery workers, hunters and trappers. Another important factor which will continue to result in a decline in demand for labour in occupations from Group 7 is mass production, which is displacing handicraft work in Europe. So the share of blacksmiths, glass-makers and potters by 2020 is projected to decrease by $16-17 \%$ compared to 2010 . Printers will suffer the greatest reduction as a group - the corresponding indicator for 2020 will be $27 \%$ less than those employed in that professional category in 2010 . This forecast can be explained by reduction of printing production because of the development of electronic mass media and electronic book-publishing. Finally, mechanization and computerization will lead to a reduction in the employment of various categories of clerks, such as library and mail clerks, as well as secretaries and keyboard-operating clerks.

Table 2. Top-20 most dynamically expanding and Top-20 most dynamically decreasing occupations in the European labour market, 2010-2020

\begin{tabular}{|c|l|c|c|l|c|}
\hline № & $\begin{array}{c}\text { Occupational groups according to } \\
\text { ISCO-88 }\end{array}$ & $\begin{array}{c}\text { Dynamics of the } \\
\text { size of the group } \\
\text { in 2010-2020 } \\
\text { related to the size } \\
\text { of the group in } \\
\mathbf{2 0 1 0} \%\end{array}$ & № & $\begin{array}{c}\text { Occupational groups according to } \\
\text { ISCO-88 }\end{array}$ & $\begin{array}{c}\text { Dynamics of the } \\
\text { size of the group } \\
\text { in 2010-2020 } \\
\text { related to the size } \\
\text { of the group in } \\
\mathbf{2 0 1 0} \%\end{array}$ \\
\hline 1 & 521 Fashion and other models & 37.9 & 1 & $\begin{array}{l}734 \text { Printing and related trades } \\
\text { workers }\end{array}$ & -26.9 \\
\hline 2 & $\begin{array}{l}333 \text { Special education teaching } \\
\text { associate professionals }\end{array}$ & 34.0 & 2 & $\begin{array}{l}744 \text { Pelt, leather and shoemaking } \\
\text { trades workers }\end{array}$ & -24.8 \\
\hline 3 & $\begin{array}{l}346 \text { Social work associate profes- } \\
\text { sionals }\end{array}$ & 32.5 & 3 & $\begin{array}{l}741 \text { Food processing and related } \\
\text { trades workers }\end{array}$ & -22.1 \\
\hline 4 & $\begin{array}{l}\text { 422 Client information clerks } \\
\text { (n) }\end{array}$ & 30.3 & 4 & $\begin{array}{l}743 \text { Textile, garment and related } \\
\text { trades workers }\end{array}$ & -18.0 \\
\hline 5 & $\begin{array}{l}321 \text { Life science technicians and } \\
\text { related associate professionals }\end{array}$ & 28.5 & 5 & 412 Numerical clerks & -17.9 \\
\hline
\end{tabular}




\begin{tabular}{|c|c|c|c|c|c|}
\hline № & $\begin{array}{c}\text { Occupational groups according to } \\
\text { ISCO-88 }\end{array}$ & $\begin{array}{l}\text { Dynamics of the } \\
\text { size of the group } \\
\text { in } 2010-2020 \\
\text { related to the size } \\
\text { of the group in } \\
2010, \%\end{array}$ & № & $\begin{array}{l}\text { Occupational groups according to } \\
\text { ISCO-88 }\end{array}$ & $\begin{array}{l}\text { Dynamics of the } \\
\text { size of the group } \\
\text { in } 2010-2020 \\
\text { related to the size } \\
\text { of the group in } \\
2010, \%\end{array}$ \\
\hline 6 & $\begin{array}{l}812 \text { Metal-processing-plant } \\
\text { operators }\end{array}$ & 27.4 & 6 & $\begin{array}{l}711 \text { Miners, shotfirers, stone cut- } \\
\text { ters and carvers }\end{array}$ & -17.6 \\
\hline 7 & $\begin{array}{l}911 \text { Street vendors and related } \\
\text { workers }\end{array}$ & 25.6 & 7 & $\begin{array}{l}414 \text { Library, mail and related } \\
\text { clerks }\end{array}$ & -17.2 \\
\hline 8 & $\begin{array}{l}933 \text { Transport labourers and } \\
\text { freight handlers }\end{array}$ & 25.4 & 8 & $\begin{array}{l}732 \text { Potters, glass-makers and } \\
\text { related trades workers }\end{array}$ & -17.2 \\
\hline 9 & $\begin{array}{l}244 \text { Social science and related } \\
\text { professionals }\end{array}$ & 24.3 & 9 & $\begin{array}{l}411 \text { Secretaries and keyboard- } \\
\text { operating clerks }\end{array}$ & -16.8 \\
\hline 10 & $\begin{array}{l}322 \text { Modern health associate } \\
\text { professionals (except nursing) }\end{array}$ & 24.0 & 10 & $\begin{array}{l}722 \text { Blacksmiths, tool-makers and } \\
\text { related trades workers }\end{array}$ & -16.2 \\
\hline 11 & $\begin{array}{l}332 \text { Pre-primary education } \\
\text { teaching associate professionals }\end{array}$ & 23.8 & 11 & $\begin{array}{l}724 \text { Electrical and electronic } \\
\text { equipment mechanics and fitters }\end{array}$ & -15.7 \\
\hline 12 & 241 Business professionals & 23.4 & 12 & $\begin{array}{l}721 \text { Metal molders, welders; } \\
\text { sheet-metal workers, structural- } \\
\text { metal preparers }\end{array}$ & -14.9 \\
\hline 13 & $\begin{array}{l}212 \text { Mathematicians, statisticians } \\
\text { and related professionals }\end{array}$ & 22.6 & 13 & 419 Other office clerks & -14.5 \\
\hline 14 & $\begin{array}{l}714 \text { Painters, building struc- } \\
\text { ture cleaners and related trades } \\
\text { workers }\end{array}$ & 20.6 & 14 & $\begin{array}{l}723 \text { Machinery mechanics and } \\
\text { fitters }\end{array}$ & -13.1 \\
\hline 15 & $\begin{array}{l}334 \text { Other teaching associate } \\
\text { professionals }\end{array}$ & 20.3 & 15 & 614 Forestry and related workers & -12.0 \\
\hline 16 & 932 Manufacturing labourers & 18.7 & 16 & $\begin{array}{l}833 \text { Agricultural and other } \\
\text { mobile-plant operators }\end{array}$ & -11.7 \\
\hline 17 & $\begin{array}{l}211 \text { Physicists, chemists and } \\
\text { related professionals }\end{array}$ & 17.3 & 17 & $\begin{array}{l}615 \text { Fishery workers, hunters and } \\
\text { trappers }\end{array}$ & -11.7 \\
\hline 18 & $\begin{array}{l}915 \text { Messengers, porters, door- } \\
\text { keepers and related workers }\end{array}$ & 15.9 & 18 & $\begin{array}{l}610 \text { Other: skilled agricultural and } \\
\text { fishery workers }\end{array}$ & -10.8 \\
\hline 19 & $\begin{array}{l}341 \text { Finance and sales associate } \\
\text { professionals }\end{array}$ & 15.2 & 19 & $\begin{array}{l}731 \text { Precision workers in metal } \\
\text { and related materials }\end{array}$ & -10.4 \\
\hline \multirow[t]{2}{*}{20} & $\begin{array}{l}348 \text { Religious associate profes- } \\
\text { sionals }\end{array}$ & 14.7 & 20 & $\begin{array}{l}834 \text { Ships }^{6} \text { deck crews and related } \\
\text { workers }\end{array}$ & -10.0 \\
\hline & $\begin{array}{l}421 \text { Cashiers, tellers and related } \\
\text { clerks }\end{array}$ & 14.7 & & & \\
\hline
\end{tabular}

Source: Own calculations on the basis of Cedefop Forecasts Data. 


\section{Occupational structure: forecasting total demand}

In the previous section, we considered the forecasted estimates of the net increase in employment by occupational group for Europe in 2020. However, in addition to net growth, forecasts should also evaluate the number of jobs that will become available as a result of retirement, death, and workers changing their professions. At the same time, the replacement demand may differ significantly from the trends of net employment growth. One of the reasons here is the differences in age structure of various occupational groups. For example, the need for the replacement will be especially high among certain categories of unskilled labour, legislators and major officials, the proportion of older age groups among which is much higher than average.

Table 3 shows the changes in the forecasted labour demand, broken down by net and replacement demand for different occupational groups (two-digit level of ISCO88 classification) in the European labour market between 2010 and 2020. A review of the two components of demand for labour leads to one important conclusion: in all occupations, the need for labour replacement will significantly exceed the need for a new workforce. The dynamics of the total number of jobs that will become vacant in the future will be positive for all occupational groups, although the rate of this increase will be different.

Table 3. Total labour demand by occupational group, European countries, 2010-2020.

\begin{tabular}{|l|c|c|c|c|c|c|}
\hline \multirow{2}{*}{$\begin{array}{c}\text { Occupational groups according to } \\
\text { ISCO-88 }\end{array}$} & \multicolumn{2}{|c|}{ Total labour demand 2010-2020 (,000) } & \multicolumn{2}{c|}{$\begin{array}{c}\text { Dynamics of labour demand 2010-2020 } \\
\text { (related to 2010 level, \%) }\end{array}$} \\
\cline { 2 - 7 } & $\begin{array}{c}\text { Expansion } \\
\text { demand }\end{array}$ & $\begin{array}{c}\text { Replacement } \\
\text { demand }\end{array}$ & $\begin{array}{c}\text { Total re- } \\
\text { quirement }\end{array}$ & $\begin{array}{c}\text { Expansion } \\
\text { demand }\end{array}$ & $\begin{array}{c}\text { Replacement } \\
\text { demand }\end{array}$ & $\begin{array}{c}\text { Total } \\
\text { requirement }\end{array}$ \\
\hline $\begin{array}{l}\text { 1 Legislators, senior officials and } \\
\text { managers }\end{array}$ & $\mathbf{1 5 5 6 . 0}$ & $\mathbf{8 6 5 9 . 0}$ & $\mathbf{1 0 2 1 5 . 0}$ & $\mathbf{8 . 0}$ & $\mathbf{4 4 . 5}$ & $\mathbf{5 2 . 5}$ \\
\hline 11 Legislators and senior officials & 27.0 & 275.0 & 302.0 & 6.5 & 67.5 & 74.0 \\
\hline 12 Corporate managers & 1016.0 & 4184.0 & 5200.0 & 9.2 & 38.0 & 47.2 \\
\hline 13 Managers of small enterprises & 513.0 & 4200.0 & 4713.0 & 6.4 & 52.4 & 58.8 \\
\hline 2 Professionals & $\mathbf{2 8 1 9 . 0}$ & $\mathbf{1 2 1 3 8 . 0}$ & $\mathbf{1 4 9 5 7 . 0}$ & $\mathbf{8 . 2}$ & $\mathbf{3 5 . 4}$ & $\mathbf{4 3 . 7}$ \\
\hline $\begin{array}{l}\text { 21 Physical, mathematical and } \\
\text { engineering science professionals }\end{array}$ & 1237.0 & 2517.0 & 3754.0 & 142.0 & 29.0 & 43.2 \\
\hline $\begin{array}{l}\text { 22 Life science and health } \\
\text { professionals }\end{array}$ & -45.0 & 1734.0 & 1688.0 & -1.1 & 40.9 & 39.8 \\
\hline 23 Teaching professionals & -659.0 & 3633.0 & 2973.0 & -7.2 & 39.8 & 32.6 \\
\hline 24 Other professionals & 2286.0 & 4255.0 & 6541.0 & 18.8 & 34.9 & 53.7 \\
\hline $\begin{array}{l}\text { 3 Technicians and associate } \\
\text { professionals }\end{array}$ & $\mathbf{5 0 1 2 . 0}$ & $\mathbf{1 1 2 5 8 . 0}$ & $\mathbf{1 6 2 6 9 . 0}$ & $\mathbf{1 3 . 0}$ & $\mathbf{2 9 . 1}$ & $\mathbf{4 2 . 1}$ \\
\hline $\begin{array}{l}\text { 31 Physical and engineering } \\
\text { science associate professionals }\end{array}$ & 555.0 & 2393.0 & 2948.0 & 6.4 & 27.5 & 33.9 \\
\hline
\end{tabular}




\begin{tabular}{|c|c|c|c|c|c|c|}
\hline \multirow{2}{*}{$\begin{array}{l}\text { Occupational groups according to } \\
\text { ISCO-88 }\end{array}$} & \multicolumn{3}{|c|}{ Total labour demand $2010-2020(, 000)$} & \multicolumn{3}{|c|}{$\begin{array}{c}\text { Dynamics of labour demand 2010-2020 } \\
\text { (related to } 2010 \text { level, \%) }\end{array}$} \\
\hline & $\begin{array}{c}\text { Expansion } \\
\text { demand }\end{array}$ & $\begin{array}{l}\text { Replacement } \\
\text { demand }\end{array}$ & $\begin{array}{l}\text { Total re- } \\
\text { quirement }\end{array}$ & $\begin{array}{l}\text { Expansion } \\
\text { demand }\end{array}$ & $\begin{array}{l}\text { Replacement } \\
\text { demand }\end{array}$ & $\begin{array}{l}\text { Total } \\
\text { requirement }\end{array}$ \\
\hline $\begin{array}{l}32 \text { Life science and health } \\
\text { associate professionals }\end{array}$ & 727.0 & 1816.0 & 2543.0 & 11.3 & 28.3 & 39.7 \\
\hline $\begin{array}{l}33 \text { Teaching associate } \\
\text { professionals }\end{array}$ & 697.0 & 939.0 & 1636.0 & 23.6 & 31.8 & 55.5 \\
\hline 34 Other associate professionals & 3032.0 & 6110.0 & 9142.0 & 14.7 & 29.7 & 44.4 \\
\hline 4 Clerks & -1786.0 & 7369.0 & 5583.0 & -7.3 & 30.2 & 22.9 \\
\hline 41 Office clerks & -2847.0 & 6107.0 & 3260.0 & -14.5 & 31.1 & 16.6 \\
\hline 42 Customer services clerks & 1061.0 & 1262.0 & 2323.0 & 22.5 & 26.8 & 49.3 \\
\hline $\begin{array}{l}5 \text { Service workers and shop and } \\
\text { market sales workers }\end{array}$ & 1170.0 & 8676.0 & 9845.0 & 3.6 & 26.8 & 30.4 \\
\hline $\begin{array}{l}51 \text { Personal and protective } \\
\text { services workers }\end{array}$ & 554.0 & 5908.0 & 6461.0 & 2.6 & 28.2 & 30.8 \\
\hline $\begin{array}{l}52 \text { Models, salespersons and } \\
\text { demonstrators }\end{array}$ & 616.0 & 2768.0 & 3384.0 & 5.4 & 24.3 & 29.7 \\
\hline $\begin{array}{l}6 \text { Skilled agricultural and fishery } \\
\text { workers }\end{array}$ & -905.0 & 5445.0 & 4540.0 & -9.4 & 56.4 & 47.0 \\
\hline 7 Craft and related trades workers & -1744.0 & 7646.0 & 5901.0 & -6.0 & 26.2 & 20.2 \\
\hline $\begin{array}{l}71 \text { Extraction and building trades } \\
\text { workers }\end{array}$ & 650.0 & 3367.0 & 4017.0 & 5.0 & 26.0 & 31.0 \\
\hline $\begin{array}{l}72 \text { Metal, machinery and related } \\
\text { trades workers }\end{array}$ & -1575.0 & 2830.0 & 1255.0 & -14.5 & 26.1 & 11.6 \\
\hline $\begin{array}{l}73 \text { Precision, handicraft, craft } \\
\text { printing and related trades workers }\end{array}$ & -190.0 & 389.0 & 199.0 & -15.9 & 32.6 & 16.7 \\
\hline $\begin{array}{l}74 \text { Other craft and related trades } \\
\text { workers }\end{array}$ & -630.0 & 1059.0 & 429.0 & -15.0 & 25.2 & 102.0 \\
\hline $\begin{array}{l}8 \text { Plant and machine operators and } \\
\text { assemblers }\end{array}$ & -22.0 & 5263.0 & 5241.0 & -0.1 & 29.5 & 29.4 \\
\hline $\begin{array}{l}81 \text { Stationary plant and related } \\
\text { operators }\end{array}$ & 137.0 & 490.0 & 627.0 & 6.7 & 24.0 & 30.8 \\
\hline $\begin{array}{l}82 \text { Machine operators and } \\
\text { assemblers }\end{array}$ & 70.0 & 1534.0 & 1605.0 & 1.1 & 24.0 & 25.1 \\
\hline $\begin{array}{l}83 \text { Drivers and mobile plant } \\
\text { operators }\end{array}$ & -229.0 & 3239.0 & 3010.0 & -2.4 & 34.4 & 31.9 \\
\hline 9 Elementary occupations & 2500.0 & 8716.0 & 11216.0 & 10.7 & 37.3 & 48.0 \\
\hline $\begin{array}{l}91 \text { Sales and services elementary } \\
\text { occupations }\end{array}$ & 1020.0 & 6392.0 & 7412.0 & 6.7 & 42.1 & 48.9 \\
\hline $\begin{array}{l}92 \text { Agricultural, fishery and } \\
\text { related labourers }\end{array}$ & 267.0 & 792.0 & 1060.0 & 14.5 & 43.1 & 57.6 \\
\hline
\end{tabular}




\begin{tabular}{|l|c|c|c|c|c|c|}
\hline \multirow{2}{*}{$\begin{array}{c}\text { Occupational groups according to } \\
\text { ISCO-88 }\end{array}$} & \multicolumn{2}{|c|}{ Total labour demand 2010-2020 (,000) } & \multicolumn{2}{|c|}{$\begin{array}{c}\text { Dynamics of labour demand 2010-2020 } \\
\text { (related to 2010 level, \%) }\end{array}$} \\
\cline { 2 - 7 } & $\begin{array}{c}\text { Expansion } \\
\text { demand }\end{array}$ & $\begin{array}{c}\text { Replacement } \\
\text { demand }\end{array}$ & $\begin{array}{c}\text { Total re- } \\
\text { quirement }\end{array}$ & $\begin{array}{c}\text { Expansion } \\
\text { demand }\end{array}$ & $\begin{array}{c}\text { Replacement } \\
\text { demand }\end{array}$ & $\begin{array}{c}\text { Total } \\
\text { requirement }\end{array}$ \\
\hline $\begin{array}{l}\text { 93 Labourers in mining, } \\
\text { construction, manufacturing and } \\
\text { transport }\end{array}$ & 1213.0 & 1532.0 & 2744.0 & 19.1 & 24.1 & 43.2 \\
\hline All occupations & 8376.6 & 75309.1 & 83685.7 & 3.6 & 32.7 & 36.3 \\
\hline
\end{tabular}

Source: Cedefop Forecasts Data.

As can be seen from Table 3, the demand for replacement workers as a whole in the European countries will increase by 33\% during 2010-2020. At the same time, the most pronounced increase in the need for labour replacement will take place among such occupations as legislators and senior officials, managers of small enterprises and skilled agricultural and fishery workers. The increase in replacement demand for the labour force in these occupations in comparison with 2010 will amount to more than $50 \%$. As a rule, many professionals engaged in these occupations are middle-aged or seniors. Therefore, the need for the replacement of the labour force in connection with the retirement of workers will be particularly acute here. In all other occupations the forecasted increase in the demand for the replacement of the labour force will be less apparent, but nowhere will this figure fall below $24 \%$.

Summing up the indicators of net and replacement demand for various occupational groups, we can conclude that the greatest increase in total labour demand by 2020 will occur among managers of small enterprises, corporate managers, "other" professionals, teaching associate professionals, customer services clerks, skilled agricultural and fishery workers, sales and services-related elementary occupations, as well as agricultural, fishery and related labourers. In all these occupations, the increase in the total labour force requirement in 2020 compared to 2010 will be approximately $50 \%$ or even more.

The growth in demand for labour will be significantly less for craft and related trades workers and plant and machine operators and assemblers. The corresponding figure for metal, machinery and related trades workers, as well as other craft and related trades workers will only be about $10 \%$. It is noteworthy that this low level will be the result of a combination of a simultaneous fall in the demand for a new labour force and an increase in the need for labour replacement that will characterize these occupations.

\section{Conclusion}

In this paper, we analyzed the projected changes in labour demand in the European labour market in the context of an array of professional categories, which made it possible to clarify future trends. 
Forecasts of the occupational and skill structure of the workforce are an important component of nationwide forecasts in developed European countries. The Cedefop prepares forecasts for the European Union as a whole, in which some transition economies have recently been included. Although such forecasts are no longer considered direct "guidance," particularly with respect to education or business, they continue to play an important role, outlining possible changes in the future demand for certain categories of workers.

Summing up, we can say that the main trend for the next decade will be an increasing demand for both mid-level and highly qualified specialists. The need for health workers and other occupations that provide a scientific and technical breakthrough will grow especially rapidly. The increased demand for mid-level employees is due to the fact that those employed in such occupations are increasingly taking on certain functions that were previously performed by more qualified personnel, thus ensuring a more efficient distribution of labour within a skilled workforce segment.

At the same time, demand for the least skilled workers is also expected to increase. This will happen despite the fact that the forecasts indicate a forthcoming decrease in the number of qualified and semi-skilled workers' occupations, which is directly related to the fall in the share of industrial production in developed countries. However, the fact is that the ongoing "mechanization" of many labour functions can't eliminate the need for many "elementary" occupations. It should be borne in mind that the preservation of such jobs allows workers with low, often only initial education to remain in the labour market and not depend on social assistance.

In developed market economies, there is a clear tendency towards a reduction in the demand for labour among many "white-collar" occupations, which require a lower skill level. The forthcoming decrease in demand in many categories of employees in this group is associated with the further spread of modern computer technology and the automation of many routine functions previously performed by office workers. At the same time, the demand for employees engaged in services is expected to "take off," that is, employees who have direct contact with consumers of goods or services produced. The number of jobs in trade will grow at an average level for the economy, but we should not forget that trade workers will remain one of the largest groups in the workforce.

As the forecasts of the occupational structure of the economy show, the overall demand for labour will depend not only on the dynamics of the newly created jobs, but also on the need to replace labour in connection with an aging population, withdrawal from the labour market and labour mobility. That is why the total demand for labour in all professional groups will be positive, although in some of them it will arise mainly due to the need to fill existing jobs.

\section{References}

Autor D., Dorn D. (2013) The Growth of Low-Skill Service Jobs and the Polarization of the US Labor Market. American Economic Review, vol. 103, no 5, pp. 1553-1597. 
CEDEFOP (2012) Future Skills Supply and Demand in Europe. Forecast 2012. Research Paper no 26. Luxembourg: Publications Office of the European Union.

CEDEFOP (2014) Coping with Changes in International Classification of Sectors and Occupations. Research paper no 43. Luxembourg: Publications Office of the European Union.

Crouch C. (2010) Occupational Structure and Social Models in European Societies. Working Paper, August. University of Warwick Business School.

Denison E. (1962) The Sources of Economic Growth and the Alternatives Before US. Supplementary Paper no 13, N.Y. Committee for Economic Development.

ILO (2012) International Standard Classification of Occupations. Structure, Group Definitions and Correspondence Tables, vol. 1.

Hughes G. (1993) Projecting the Occupational Structure of Employment in OECD Countries. Working paper no 10. Paris: OECD

Pomazkin D.V. (2014) Vliyanie na rynok tryda izmenenii polovozrastnoi stryktyry [Influence of Age and Gender Structure of Population on the Labour Market]. Pension Review, no 1 (January - March). Available at: http://pensionobserver.ru/arxiv/1-17-yanvar-mart-2014-g/v-czentre-vnimaniya/vliyanie-naryinok-truda-izmenenij-polovozrastnoj-struktury (accessed 4 November 2016). (In Russian.)

Stehrer R. et al. (2013). Changes in the Classification of Occupations: The Implications for Skills Projections. Mid-term Skills Supply and Demand Forecast. Warwick: IER, Institute for Employment Research.

Zukersteinova A. (ed.) (2007) Towards European Skill Needs Forecasting. CEDEFOP. 


\title{
Профессиональная структура рабочей силы в странах Европы: о чем свидетельствуют прогнозы?'1
}

\author{
Н.Т. Вишневская, А.А. Зудина
}

Вишневская Нина Тимофеевна - к.э.н., заместитель директора Центра трудовых исследований Национального исследовательского университета «Высшая школа экономики»; Российская Федерация, 101000, Москва, ул. Мясницкая, д. 20; E-mail: vishnev@hse.ru

Зудина Анна Алексеевна - к.соц.н., научный сотрудник Центра трудовых исследований Национального исследовательского университета «Высшая школа экономики»; Российская Федерация, 101000, Москва, ул. Мясницкая, д. 20; E-mail: azudina@hse.ru

В работе анализируется будущее состояние профессиональной структуры рабочей силы в европейских странах ОЭСР. Анализ прогнозных оценок структуры рабочей силы в профессиональном разрезе позволяет ответить на вопрос о качестве вновь создаваемых рабочих мест, а следовательно, о будущей эффективности функционирования рынка труда. Выявление особенностей спроса на отдельные профессиональные группы в странах Европы представляется полезным для понимания того, насколько процессы, происходящие на российском рынке труда, соответствуют мировым трендам. В работе рассматриваются особенности методологии составления прогнозов и основные подходы к прогнозированию изменения профессиональной структуры, характеристики динамики спроса на труд представителей отдельных профессий, а также причины увеличения и падения спроса на те или иные профессии. Как показал проведенный анализ, основной тенденцией на рынке труда на ближайшее десятилетие станет увеличение значимости специалистов средней и высшей квалификации. Особенно активно возрастет потребность в работниках здравоохранения, а также профессиях, обеспечивающих научно-технический прорыв. Одновременно с этим ожидается повышение спроса на труд самых неквалифицированных работников, которое будет наблюдаться на фоне снижения численности квалифицированных и полуквалифицированных рабочих профессий, вызванное падением доли промышленного производства в экономике развитых стран и проиессами глобализации. Происходящая «машинизация» многих трудовых функций пока еще не может свести на нет потребность во многих профессиях низкой квалификации. Сохранение подобных рабочих мест позволяет работникам с низким образованием оставаться на рынке труда и не зависеть от системы социальной помощи. Для всех стран с развитой рыночной экономикой достаточно четко проявляется тенденция к сокращению спроса на труд таких «беловоротничковых» профессий, как офисные служащие. Предстоящее снижение потребности в этой категории занятых связано с дальнейшим распространением современных компьютерных технологий и автоматизацией многих рутинных функций, ранее выполняемых работниками офисов.

Ключевые слова: профессиональная структура; прогнозирование; рынок труда; Европа; ОЭСР; спрос на труд; качество рабочих мест

Для цитирования: Вишневская Н.Т., Зудина А.А. Профессиональная структура рабочей силы в странах Европы: о чем свидетельствуют прогнозы? // Вестник международных организаций. 2017. Т. 12. № 4. C. 109-129. DOI: 10.17323/1996-7845-2017-04-109

\section{Источники}

Помазкин Д.В. (2014) Влияние на рынок труда изменений половозрастной структуры // Пенсионное обозрение. Электронный журнал. № 1 (Январь - март). Режим доступа: http://pensionobserver.ru/

${ }^{1}$ Статья поступила в редакцию в октябре 2016 г.

Исследование осуществлено в рамках Программы прикладных исследований НИУ ВШЭ в 2016 г. 
arxiv/1-17-yanvar-mart-2014-g/v-czentre-vnimaniya/vliyanie-na-ryinok-truda-izmenenij-polovozrastnojstrukturyi (дата обращения: 04.11.2016).

Autor D., Dorn D. (2013) The Growth of Low-Skill Service Jobs and the Polarization of the US Labor Market // American Economic Review. Vol. 103. No. 5. P. 1553-1597.

CEDEFOP (2012) Future Skills Supply and Demand in Europe. Forecast 2012: Research Paper No. 26. Luxembourg: Publications Office of the European Union.

CEDEFOP (2014) Coping with Changes in International Classification of Sectors and Occupations: Research paper No. 43. Luxembourg: Publications Office of the European Union.

Crouch C. (2010) Occupational Structure and Social Models in European Societies: Working Paper, August. University of Warwick Business School.

Denison E. (1962) The Sources of Economic Growth and the Alternatives Before US: Supplementary paper No. 13. N.Y. Committee for Economic Development.

ILO (2012) International Standard Classification of Occupations. Structure, Group Definitions and Correspondence Tables, vol. 1.

Hughes G. (1993) Projecting the Occupational Structure of Employment in OECD countries: Working paper No. 10. Paris: OECD.

Stehrer R. et al. (2013) Changes in the Classification of Occupations: The Implications for Skills Projections. Mid-term Skills Supply and Demand Forecast. Warwick: IER, Institute for Employment Research.

Zukersteinova A. (ed.) (2007) Towards European Skill Needs Forecasting. CEDEFOP. 